\title{
OPTIMAL BULKING AGENT PARTICLE SIZE AND USAGE FOR HEAT RETENTION AND DISINFECTION IN DOMESTIC WASTEWATER SLUDGE COMPOSTING
}

Teresa Gea, Raquel Barrena, Adriana Artola and Antoni Sánchez*

Composting Research Group

Departament Enginyeria Química

Escola Tècnica Superior d'Enginyeria

Universitat Autònoma de Barcelona

08913-Bellaterra (Barcelona), Spain.

* Corresponding author: Antoni Sánchez

Phone: 34-93-5811019

Fax: 34-93-5812013

E-mail address: antoni.sanchez@uab.cat 


\begin{abstract}
Composting of two types of sludge produced in wastewater treatment plants, raw sludge (RS) and anaerobically digested sludge (ADS), has been systematically studied by means of the experimental design technique. The results have been analyzed using a full factorial experimental design in order to determine the optimal conditions for composting such sludges in terms of bulking agent particle size and bulking agent:sludge volumetric ratio, two of the key parameters to ensure an optimal performance of the composting process. The objective function selected was a simulated death kinetics of Salmonella, which was chosen as a model pathogen microorganism to represent the disinfection of the material. For both types of sludge, optimal values were found at $5 \mathrm{~mm}$ bulking agent particle size and 1:1 bulking agent:sludge volumetric ratio when a Gaussian function was fitted to the experimental data. Pilot scale experiments using optimal values obtained were successfully undertaken and confirmed a full disinfection of the sludge by means of the composting process. A mathematical model to simulate the disinfection performance of a composting material is presented. The model can be applied to simulate the disinfection performance of a given pathogen.
\end{abstract}

Keywords: Anaerobically Digested Sludge, Composting, Disinfection, Experimental Design, Optimization, Raw Sludge, Salmonella, Simulation. 


\section{Notation}

a: Coefficient of Gaussian function (dimensionless).

b: Coefficient of Gaussian function (mm).

c: Coefficient of Gaussian function (dimensionless).

C: Pre-exponential factor $\left(\mathrm{min}^{-1}\right)$

$\mathrm{E}_{\mathrm{D}}$ : Inactivation energy $(\mathrm{Kcal} / \mathrm{mol})$.

$\mathrm{k}_{\mathrm{D}}$ : Thermal inactivation coefficient $\left(\mathrm{min}^{-1}\right)$.

$\mathrm{n}$ : Viable pathogen population (dimensionless).

r: Coefficient of correlation.

T: Temperature $\left({ }^{\circ} \mathrm{C}\right.$ or $\left.\mathrm{K}\right)$.

$\mathrm{t}$ : Time (min or day).

$\mathrm{X}_{1}$ : Bulking agent particle size $(\mathrm{mm})$.

$\mathrm{X}_{2}$ : Bulking agent:sludge volumetric ratio (dimensionless).

$\mathrm{X}_{10}$ : Coefficient of Gaussian function $(\mathrm{mm})$.

$\mathrm{X}_{20}$ : Coefficient of Gaussian function (dimensionless). 


\section{Introduction}

Handling and disposal of large quantities of sludge is a problem derived from the growing environmental awareness, which is leading to an increasing number of wastewater treatment plants entering into operation (Lasaridi et al., 2000). At present, there is a tendency in Europe towards an agricultural application of sludge in order to reuse its organic matter and nutrient content. The main legal restriction to land application of the sludge is given by its content of heavy metals and potentially toxic compounds. The European Commission is preparing a new Directive on the biological treatment of organic wastes, which intends to regulate among other quality parameters the degree of sludge disinfection before its application to land (European Commission, 2000). The two alternatives proposed by the Directive to ensure effective pathogen elimination are thermophilic anaerobic digestion and composting. Sewage sludge composting can effectively decompose organic matter of sewage sludge into a stable end product. In addition, the high temperature reached due to the metabolic heat generated during the thermophilic phase of the composting process is effective in destroying the pathogens allowing the final product to be safely used as fertiliser or soil conditioner (Wong and Fang, 2000). For sludge composting, in the draft of the above mentioned Directive different combinations of temperature and time are indicated in order to reach the proper disinfection of the final product (temperatures over $55^{\circ} \mathrm{C}, 20$ days for conventional aerobic treatments or 20 hours for $55^{\circ} \mathrm{C}$ for advanced aerobic stabilisation treatments; European Commission, 2000). Other international rules on sludge disinfection by composting propose similar timetemperature conditions (U.S. Environmental Protection Agency, 1995). 
Main factors influencing the composting process are temperature, water content, oxygen concentration in the composting matrix, porosity and free air space (FAS). Temperature is simultaneously a consequence of the composting process (microbial metabolism) and a control parameter. Temperatures providing the maximum degradation rate are in the range $40-70^{\circ} \mathrm{C}$ (Haug, 1993). The optimum water content has been established within 40-60\%. Oxygen concentration within the composting matrix should not be lower than $5-7 \%$. Proper aeration of the composting material will only be possible if enough porosity and FAS are provided. Optimum values of FAS are around 30\% (Haug, 1993).

The water content of sewage sludge is usually too high for composting even if a dewatering treatment is applied to this material. In a majority of cases the addition of a bulking agent is necessary. A bulking agent is a material that provides FAS and regulates the water content of the waste to be composted. Eftoda and McCartney (2004) determined the minimum bulking agent requirements to provide an optimal FAS for the composting process. Common bulking agents are fibrous carbonaceous materials with low moisture content (Morisaki et al., 1989; Sesay et al., 1997; Milne et al., 1998; Miner et al., 2001). A long list of waste materials have been proposed as bulking agents although one of the most widely used materials are wood chips (Atkinson et al., 1996; Jokela et al., 1997; Wong et al., 1997; Larsen and McCartney, 2000). Although these materials are not believed to be significantly degraded under composting conditions because of their high lignin content some recent works have reported a certain biodegradability of wood chips (Mason et al., 2004). In addition to the type of bulking agent used, its particle size and the proportion of bulking agent in the final mixture have also been emphasized as important factors in sludge 
composting processes (Morisaki et al., 1989; Wong et al., 1995; Larsen and McCartney, 2000) as well as in the modelling of the process (Haug, 1993). For instance, Barrington et al. (2002a) showed the relationship between bulking agent characteristics and the pressure drop found in a composting mass. Similar works (Liao et al. 1997; Barrington et al., 2002b) have reported the influence of the type and characteristics of bulking agent on nitrogen losses. The same relationship was also observed by Paredes et al. (1996) who also reported the influence of the type of bulking agent on organic matter mineralization and stabilization using the Rutgers composting system (Finstein, 1989). Although all these parameters are critical for the performance of the composting process, there are few references where the influence of bulking agent characteristics on material disinfection has been studied (Mason et al., 2004). It is particularly remarkable the work of Ros et al. (2006) where several biological parameters including pathogen content or ecotoxicity are determined in relation to bulking agent ratio. However these results were obtained in pig slurry composting.

Salmonella is widely used in sludge decontamination studies (Jepsen et al., 1997; Gantzer et al., 2002) as an indicator of pathogen contamination (Hassen et al., 2001; Sidhu et al., 2001). Nevertheless there is an absence of scientific consensus on the conditions needed to remove Salmonella from a composting material. Although there are several studies that use this microorganism as an indicator of material disinfection, standard conditions for Salmonella removal, as temperature and time of exposition and operational procedure or type of process, have not been established (Watanabe et al., 1997; Deportes et al., 1998; Hassen et al., 2001; Maboeta and Van Rensburg, 2003; Paluszak et al., 2003).

The objective of this work is to examine the influence of the bulking agent particle size and bulking agent:sludge volumetric ratio on the composting process of two different 
types of sewage sludge: dewatered raw sludge (RS) and dewatered anaerobically digested sludge (ADS). The full composite factorial experimental design technique is applied to plan the experiments necessary to study the influence of the mentioned factors on sludge composting process and to determine the relationship among them. The variable monitored is the temperature profile reached in a composting experiment. As stated above, the combination of the two parameters (temperature and time) will determine the degree of sludge disinfection. Salmonella was selected as a model pathogen to calculate the disinfection degree using a first order decay model, since this microorganism is widely used in sludge contamination studies (Jepsen et al., 1997; Gantzer et al., 2002).

\section{Materials and Methods}

\subsection{Sludge and bulking agent}

The materials studied were: dewatered raw sludge (composed of primary and activated sludge) from the urban wastewater treatment plant (WWTP) of La Garriga (Barcelona, Spain) and dewatered anaerobically digested sludge from the urban WWTP of Granollers (Barcelona, Spain). In both WWTP the same purification system is applied to wastewater: physical primary treatment and aerobic biological treatment by activated sludge. In La Garriga WWTP, the surplus sludge obtained in the biological treatment is mixed with sludge obtained in the primary decanters and dewatered by centrifugation. In Granollers WWTP, the primary and biological sludge mixture is anaerobically digested and then the resulting sludge is dewatered by centrifugation. Wood chips from a local carpentry 
were used as bulking agent. The chips consisted of a variable mixture of pine and beech tree wood. The characteristics of these materials are presented in Table 1.

Sludge-wood chips mixtures were prepared by hand after screening of the bulking agent. All mixtures presented a range of moisture content of $50-75 \%$. A semi-industrial sieve (Filtra Vibración, FT-400, Barcelona, Spain) was used for wood chips screening. Three different screens $(20,10$ and $5 \mathrm{~mm}$ mesh) were used.

\subsection{Composting experiments}

Laboratory-scale experiments were undertaken using 4.5-L Dewar® vessels (KGWIsotherm, Karlsruhe, Germany), conditioned for composting. A perforated cork lid was conditioned for temperature monitoring and air supply and a rigid wire net was placed near the bottom of the vessel to separate the composting material from possible leachates. In previous experiments, Dewar vessels performed similarly to other laboratory composters (Gea et al., 2003).

Pilot tests were undertaken in a 100-L static composter (Figure 1). The reactor (length $50 \mathrm{~cm}$, width $40 \mathrm{~cm}$, height $50 \mathrm{~cm}$ ) was placed horizontally with a slight inclination to permit the collection of leachates. A plastic mesh was fitted at the bottom of the recipient to support the material and separate it from possible leachates. A $3 \mathrm{~cm}$ polyurethane foam layer provided thermal insulation. Several holes were perforated through the walls of the vessel to permit air movement, leachates removal and the insertion of different probes. An $\mathrm{O}_{2}$-content based control provided the air for the composting process. A complete description of this reactor is provided in a previous work (Gea et al. 2004). 


\subsection{Temperature, $\mathrm{O}_{2}$ and $\mathrm{CO}_{2}$ monitoring}

Laboratory scale: Pt-100 sensors were used for temperature monitoring in the 4.5L Dewar® vessels placed in the material to have a measuring point at $1 / 2$ of the height of the material in the vessel. Temperature sensors were connected to a data acquisition system (DAS-8000, Desin, Spain) which is connected to a standard personal computer. The system allows, by means of the proper software (Proasis ${ }^{\circledR}$ Das-Win 2.1, Desin, Spain), the continuous on-line visualisation and registration of the temperature. $\mathrm{O}_{2}$ content was measured with a portable $\mathrm{O}_{2}$ detector (Oxy-ToxiRAE, RAE).

Pilot scale: Four Pt-100 sensors (Desin mod. SR-NOH) inserted at different points inside the 100-L tank were used for monitoring the temperature in the pilot scale composting experiments. Temperature average values are presented. After aspiration from the sample, oxygen and $\mathrm{CO}_{2}$ concentration in interstitial air were monitored with an oxygen sensor (Sensox, Sensotran, Spain) and an infrared detector (Sensontran I.R., Sensotran, Spain) respectively. All sensors were connected to a self-made data acquisition system. Oxygen was controlled by means of a feedback oxygen control which automatically supplied fresh air to the reactor by means of a flow meter (20 L/min) (MR3A18SVVT, Sensotran, Spain) to maintain an oxygen concentration over $10 \%$. The specific aeration rates during the thermophilic period were $0.721 \cdot \mathrm{min}^{-1} \cdot \mathrm{kg} \mathrm{TS}^{-1}$ for ADS and $1.141 \cdot \mathrm{min}^{-1} \cdot \mathrm{kg}$ $\mathrm{TS}^{-1}$ for RS, respectively. 


\subsection{Analytical methods}

Water content, total organic matter (TOM), $\mathrm{pH}$, electrical conductivity and total nitrogen (Kjeldahl method) were determined according to the standard procedures (U.S. Department of Agriculture and U.S. Composting Council, 2001).

\subsection{Respirometric tests}

A static respirometer was built according to the original model described previously (Ianotti et al., 1993) and following the modifications and recommendations given by the U.S. Department of Agriculture and U.S. Composting Council (2001). Approximately 250 $\mathrm{mL}$ of compost samples were placed in $500 \mathrm{~mL}$ Erlenmeyer flasks on a nylon mesh screen that allowed air movement under and through the solid samples. The setup included a water bath to maintain the temperature at $37^{\circ} \mathrm{C}$ during the respirometric test. Prior to the assays, samples were incubated for 18 hours at $37^{\circ} \mathrm{C}$. During all the incubation period samples were aerated with previously humidified air at the sample temperature. The drop of oxygen content in a flask containing a compost sample was monitored with a dissolved oxygen meter (Lutron 5510, Lutron Co. Ltd., Taiwan) connected to a data logger. The rate of respiration of the compost sample (Oxygen Uptake Rate, OUR, based on total organic matter content, TOM) was then calculated from the slope of oxygen level decrease according to the standard procedures (Ianotti et al., 1993). Results of the static respirometric index referred to total organic matter content are presented as an average of three replicates. 


\subsection{Numerical procedures}

Surface response graphs and fitting of equations were performed with Sigmaplot ${ }^{\circledR}$ for Windows 8.0 (SPSS Inc., 2002).

\subsection{Optimization of composting conditions}

Optimization of composting conditions was performed by means of a full composite factorial experimental design (Box et al., 1978; Trochim, 2006). The feasibility of the experimental design technique has been widely demonstrated in other related (Lay et al., 1999) and non-related fields (Sánchez et al., 2000).

The experimental design was carried out as follows:

1) Bulking agent particle size $\left(X_{1}\right)$ and bulking agent:sludge volumetric ratio $\left(X_{2}\right)$ were selected as the main factors affecting the compostability of RS and ADS. Other important factors affecting the composting process (e.g. water content and oxygen supply) were not considered in the experimental design since they were initially adjusted and maintained throughout the experiment (water content in the range of $40-60 \%$ and air supply to ensure aerobic conditions). Two bulking agents of different particle size were applied in different volumetric ratios to the same sludge.

2) The levels of the factors considered were selected according to usual composting operation (Morisaki et al., 1989; Haug, 1993; Wong et al., 1995; Larsen and McCartney, 2000):

- Bulking agent particle size $\left(\mathrm{X}_{1}\right)$ : level 1: 0-5 mm; level 2: 5-10 mm; level 3: 10-20 mm.

- Bulking agent:sludge volumetric ratio $\left(\mathrm{X}_{2}\right)$ : level 1: 1:1; level 2: 2:1; level 3: 4:1. The combinations of these levels tested experimentally are presented in Table 2. 
3) The levels and the factors considered were performed in laboratory scale composting experiments carried out in 4.5-L Dewar vessels following the full factorial experimental design. In this case, nine experiments $\left(3^{2}\right)$ for RS and ADS were respectively undertaken. Several replications randomly selected were also carried out under different conditions of the experimental design, resulting in a total value of 14 experiments.

4) Material disinfection ( $\log _{10}$ Salmonella reduction) was selected as the objective function. Usually, time-temperature conditions are given for the destruction of each pathogen. Temperatures within the range of $55-65^{\circ} \mathrm{C}$ and times from few to $60 \mathrm{~min}$ are usually recommended (Haug, 1993). On the other hand, international standards on compost disinfection require temperature above $55^{\circ} \mathrm{C}$ for a total period of 2 weeks on full scale composting facilities (U.S. Environmental Protection Agency, 1995; European Commission, 2000). First order decay models are normally used to estimate heat inactivation kinetics, according to Eq. 1:

$$
\frac{\mathrm{dn}}{\mathrm{dt}}=-\mathrm{k}_{\mathrm{D}} \mathrm{n} \quad \text { Eq. } 1
$$

where $\mathrm{n}$ is the viable cell population of a given pathogen and $\mathrm{k}_{\mathrm{D}}$ is the thermal inactivation coefficient $\left(\mathrm{min}^{-1}\right)$. Integration of Eq. 1 permits to calculate the logarithmic reduction of a pathogen population (Eq. 2):

$\log _{10}\left(\frac{\mathrm{n}_{0}}{\mathrm{n}_{\mathrm{t}}}\right)=\frac{1}{2.303} \int_{0}^{\mathrm{t}} \mathrm{k}_{\mathrm{D}} \mathrm{dt} \quad$ Eq. 2

where $k_{D}$ is an exponential function of temperature $(T)$ :

$\mathrm{k}_{\mathrm{D}}=\operatorname{Cexp}\left(-\mathrm{E}_{\mathrm{D}} / \mathrm{RT}\right) \quad$ Eq. 3 
being $\mathrm{C}$ a constant value and $\mathrm{E}_{\mathrm{D}}$ the inactivation energy for each pathogen. Both values can be obtained for several pathogens from data found in literature (Haug, 1993). For instance, U.S. EPA regulations for Class A sludges recommend a temperature of $60^{\circ} \mathrm{C}$ held for 30 min to provide a $6 \log _{10}$ reduction of Salmonella which correspond to an inactivation energy $\left(E_{D}\right)$ of $102.8 \mathrm{kcal} / \mathrm{mol}$ and a pre-exponential factor $(\mathrm{C})$ of $8.43 \cdot 10^{66} \mathrm{~min}^{-1}$. These values were calculated from Eq. 2 and 3 and were used for disinfection simulations. To minimize possible errors in the determination of $\log _{10}\left(\mathrm{n}_{0} / \mathrm{n}_{\mathrm{t}}\right)$ it is important to have accurate values of $E_{D}$, since $\log _{10}\left(n_{0} / n_{t}\right)$ presents an exponential dependence on $E_{D}$.

From composting experiments, when a curve time-temperature was obtained, $\mathrm{k}_{\mathrm{D}}$ and $\log _{10}$ reduction were calculated. The minimum temperature to perform calculations of disinfection was $45^{\circ} \mathrm{C}$, corresponding to the beginning of the thermophilic range, where most of the pathogenic microorganisms do not survive. This value of $\log _{10}\left(\mathrm{n}_{0} / \mathrm{n}_{\mathrm{t}}\right)$ is then a simulation of the disinfection performance using a model pathogen. Quantitative results of the optimal conditions of disinfection can be obtained by selecting a function that fits the whole set of experimental values for $\log _{10}\left(\mathrm{n}_{0} / \mathrm{n}_{\mathrm{t}}\right)$. In the composting experiments with RS and ADS a Gaussian function was selected (Eq. 4):

$$
\log _{10}\left(\frac{n_{0}}{n_{t}}\right)=a \exp \left(-0.5\left(\left(\frac{X_{1}-X_{10}}{b}\right)^{2}+\left(\frac{X_{2}-X_{20}}{c}\right)^{2}\right) \quad \text { Eq. } 4\right.
$$

\section{Results and discussion}

\subsection{Influence of bulking agent ratio and size on composting performance}

Table 2 summarizes the results obtained for all the experiments with the values of duration of thermophilic phase $\left(\mathrm{T}>45^{\circ} \mathrm{C}\right)$ and the product temperature-time in this phase. 
The results obtained show that there was a common tendency for RS and ADS to produce the best results in terms of disinfection temperature when the low particle sizes and the low bulking agent:sludge ratio were selected $(0-5 \mathrm{~mm}$ and $5-10 \mathrm{~mm} ; 1: 1$ and 2:1). Therefore, it can be concluded that adjusting the values of the factors studied, RS and ADS can be fully disinfected by means of composting.

In terms of composting process, the conclusion is that a low particle size of bulking agent is preferred to give the material an adequate porosity instead of using large quantities of bulking agent. Small bulking agent particles create a real porous structure and a homogeneous porous size distribution inside the material that acts as an efficient oxygen diffuser. Also, they act as effective water absorbers, which is interesting in the composting of wet wastes such as WWTP sludge (Haug, 1993). On the other hand, water content of the initial mixture needs to be adjusted to values within 40-70\% (Haug, 1993), which discards the possibility of working at bulking agent:sludge volumetric ratios lower than 1:1 (as stated before, moisture content values obtained for the initial mixtures were within 5075\%). Nevertheless, these results should be validated in the composting of sludge at industrial scale since the utilization of small particle bulking agent can cause a compaction of the material (Haug, 1993; McCartney and Chen, 2001). However, recent results obtained in the industrial composting of municipal solid wastes have shown that the utilization of big pieces of bulking agent used to prevent a loss of porosity in large composting masses does not have a significant effect on the material heat retention. In these organic wastes, the temperature is maintained for long periods given the properties of compost as a heat insulator (Barrena et al., 2006). 


\subsection{Simulation of disinfection in sludge composting}

Table 2 also summarizes the results obtained for all the experiments giving the values for $\log _{10}\left(\mathrm{n}_{0} / \mathrm{n}_{\mathrm{t}}\right)$ obtained from the mathematical model previously presented. Figure 2 shows two examples of the determination of $\mathrm{k}_{\mathrm{D}}$ which is a function of process temperature and is necessary for the determination of the objective function for different initial conditions. Figure 2 a corresponds to 5/1:1 conditions for RS composting (0-5 mm bulking agent particle size and 1:1 bulking agent:sludge volumetric ratio), where the thermophilic temperature range was completely achieved (maximum temperature: $62^{\circ} \mathrm{C}$ ) and the objective function $\left(\log _{10}\right)$ value was very high $(2339)$, which meant that the temperature profile obtained ensures total removal of Salmonella for any initial presence of this pathogen in initial material. On the other hand, whereas Figure $2 b$ corresponds to 5/2:1 (0-5 mm bulking agent particle size and 2:1 bulking agent:sludge volumetric ratio) for ADS composting, where the thermophilic temperature was reached for a shorter time (maximum temperature: $47^{\circ} \mathrm{C}$ ) and the objective function value was lower (16). In general, when thermophilic range of temperatures was achieved, values for $\log _{10}\left(\mathrm{n}_{0} / \mathrm{n}_{\mathrm{t}}\right)$ where higher than the disinfection requirements (6 $\log _{10}$ USEPA Class A sludges). On the other hand, the values of the objective function proposed in this work correlate well with those for the product temperature time obtained in the thermophilic phase but the objective function selected is more sensitive to pathogen heat inactivation.

Coefficient values for the function proposed in Eq. 4 obtained for RS and ADS are presented in Table 3. Both functions describing RS and ADS were relatively similar (coefficients with the same signal and order of magnitude) and correlation quality (r) was excellent for both cases. Objective function obtained in Table 3 for both RS and ADS was 
numerically optimized to obtain the optimal conditions to perform the composting process. Bulking agent particle size within 0-5 mm and a bulking agent:sludge volumetric ratio of 1:1 for both RS and ADS were the results obtained in the optimization of $\log _{10}\left(\mathrm{n}_{0} / \mathrm{n}_{\mathrm{t}}\right)$ using a quasi-Newton method within the experimental domain. These results were in agreement with those presented in Table 2, and corresponded to the higher values of the objective function.

Figure 3 shows the surface responses $\left(\log _{10}\left(\mathrm{n}_{0} / \mathrm{n}_{\mathrm{t}}\right)\right)$ obtained for RS and ADS. A similar behaviour was observed for both types of sludge. In general, values of objective function for RS were higher (Figure 3a) than those obtained for ADS (Figure 3b). This was in accordance to the fact that the organic matter content of ADS was lower than RS (Table 1) and, consequently, organic matter suitable for degradation could be more abundant in $\mathrm{RS}$, although the value of organic matter content obtained by combustion of the sample may not be a good indicator of biodegradable organic matter content (Barrena et al., 2005).

The temperature profiles obtained in composting experiments suggested that thermophilic conditions and effective disinfection could be assumed for values of objective function higher than 10 (equivalent to a $10^{10}$ reduction of pathogens), which implied a restricted zone in the case of RS and ADS (Figure 3) and demonstrated that it was crucial to select an optimal initial mixture to produce an effective disinfection of the material. Optimal composting conditions were found for small particle size of bulking agent and low bulking agent: sludge volumetric ratio, and the best results were produced when bulking agent size was 0-5 mm and volumetric ratio was 1:1 (normalized values: $X_{1}=-1, X_{2}=-1$ ). At full scale these results are likely to be more favourable in terms of disinfection because of the thermal inertia effect associated to large composting masses (Barrena et al. 2006). 


\subsection{Sludge disinfection at pilot scale}

Two experiments were undertaken in a 100-L composting reactor to corroborate the results obtained from the experimental design technique as optimal conditions for sludge composting in 4.5-L vessels. Each experiment correspond to one of the studied sludges (RS and ADS) mixed with 0-5 mm wood chips in a sludge-wood chips volumetric ratio of 1:1. The results obtained (temperature profiles, $\mathrm{O}_{2}$ concentration in the compost matrix and $\mathrm{CO}_{2}$ concentration in exhaust gases) are presented in Figure 4 (4a for RS and $4 \mathrm{~b}$ for ADS). The results of the respirometric assays in terms of OUR and respiration quotient $\left(\mathrm{RQ}, \mathrm{CO}_{2}\right.$ produced/ $\mathrm{O}_{2}$ consumed) are also included. Peaks in the $\mathrm{CO}_{2}$ and $\mathrm{O}_{2}$ profiles corresponded to the entrance of fresh air to the composter during material sampling. The strong variation in $\% \mathrm{O}_{2}$ profile in Figure $4 \mathrm{~b}$ (ADS) between days 18 and 20 was due to a mechanical failure in the aeration system.

Values of the objective function calculated for the two pilot scale experiments were 1626 and 628 for RS and ADS respectively (25 days of composting approximately), which were well correlated with 4.5-L experiments. As can be seen in Figure 4, the maximum temperature reached for the two types of sludge was approximately the same $\left(65^{\circ} \mathrm{C}\right)$, slightly higher for RS. From the objective function values and temperature and $\mathrm{O}_{2}$ profiles plotted in Figure 4 it could be stated that the porosity supplied by the bulking agent added was sufficient to overcome possible compression effects at pilot scale.

The results obtained from the respirometric tests indicate that a real stabilisation of the organic matter present in the composting matrix occurred for the two types of sludge. Initial values of OUR for RS $\left(6.68 \mathrm{mg} \mathrm{O}_{2} \cdot \mathrm{g} \mathrm{TOM}^{-1} \cdot \mathrm{h}^{-1}\right)$ were clearly higher than those for 
ADS $\left(3.74 \mathrm{mg} \mathrm{O}_{2} \cdot \mathrm{g} \mathrm{TOM}^{-1} \cdot \mathrm{h}^{-1}\right)$ as was expected according to the nature of organic matter present in the two different types of sludge. However, values obtained from day 3 to day 23 were very close to final OUR values of 1.76 and $2.00 \mathrm{mg} \mathrm{O}_{2} \cdot \mathrm{g} \mathrm{TOM}^{-1} \cdot \mathrm{h}^{-1}$ for RS and ADS respectively. These values were slightly higher than those established in the standards for mature composts $\left(0.5-1.5 \mathrm{mg} \mathrm{O}_{2} \cdot \mathrm{g} \mathrm{TOM}^{-1} \cdot \mathrm{h}^{-1}\right)$ (California Compost Quality Council, 2001) and correspond to a material at the end of the active decomposition composting phase. OUR values lower than $1 \mathrm{mg} \mathrm{O} 2 \cdot \mathrm{g} \mathrm{TOM}^{-1} \cdot \mathrm{h}^{-1}$ can be expected after a maturation period.

The respiration quotient (RQ), representing the relationship between $\mathrm{CO}_{2}$ produced and $\mathrm{O}_{2}$ consumed, is approximately equal to 1 under aerobic conditions (Atkinson et al., 1996). As can be seen if Figures $4 \mathrm{a}$ and $4 \mathrm{~b}$ are compared, values of RQ obtained for ADS were slightly higher than those obtained for RS in concordance with the degree of oxidation of the organic matter present in the two types of sludge, with ADS containing more degraded substances. However, RQ values for the two types of sludge were close to 1 (average RQ value for $\mathrm{ADS}=1.10$ and for $\mathrm{RS}=0.96$ ) reflecting the aerobic conditions existing during the composting experiments. The value of RQ was steady during the complete composting process. RQ has been routinely used in the biotechnological field (Atkinson and Mavituna, 1983) but, to our knowledge, it is rarely measured in composting processes. Since it is a characteristic value directly referred to organic waste composition, RQ may be suggested for the monitoring and control of the composting process of different wastes and to predict air requirements and $\mathrm{CO}_{2}$ production. 


\section{Conclusions}

Optimization of composting conditions at laboratory scale permitted to obtain the optimal values of bulking agent particle size: 0-5 $\mathrm{mm}$ and bulking agent:sludge volumetric ratio: 1:1 for both RS and ADS. Under these conditions, the temperature and time required to destroy Salmonella could be reached.

Pilot scale experiments under the optimal conditions obtained from the experimental design confirmed that the conditions to obtain the disinfection of the material were present. Moreover, an effective stabilization of the material took place, which was confirmed by respirometric analysis (OUR).

The adaptation of the first order decay model presented in this work is suitable for prediction of pathogen removal in a composting process. The mathematical model developed can be used for the prediction of disinfection of a given pathogen.

\section{Acknowledgements}

The authors wish to thank the interest and help of Francesc Aguilera and Carles Casas in the development of this work and Àngel Freixó (Consorci per a la Defensa de la Conca del Riu Besòs) for the supply of sludge. Financial support was provided by the Spanish Ministerio de Ciencia y Tecnología (Project REN2003-00823). 


\section{References}

Atkinson B, Mavituna, F, 1983. Biochemical Engineering and biotechnology handbook. Nature Press, New York.

Atkinson CF, Jones DD, Gauthier JJ, 1996. Biodegradabilities and microbial activities during composting of oxidation and ditch sludge. Compost Sci Util 4, 84-96.

Barrena R, Vázquez F, Gordillo MA, Gea T, Sánchez A, 2005. Respirometric assays at fixed and process temperatures to monitor composting process. Bioresource Technol 96, 1153-9.

Barrena R, Canovas C, Sánchez A, 2006. Prediction of temperature and thermal inertia effect in the maturation stage and stockpiling of a large composting mass. Waste Manage, available on-line: doi:10.1016/j.wasman.2005.07.023.

Barrington S, Choiniere D, Trigui M, Knight W, 2002a. Compost airflow resistance. Biosys Eng 81, 433-41.

Barrington S, Choiniere D, Trigui M, Knight W, 2002b. Effect of carbon source on compost nitrogen and carbon losses. Bioresource Technol 83, 189-94.

Box GEP, Hunter WG, Hunter JS, 1978. Statistics for Experimenters. Wiley, New York.

California Compost Quality Council, 2001. Compost Maturity Index. URL: http://www.crra.com/ccqc/ccqchome.htm

Deportes I, Benoit-Guyod JL, Zmirou D, Bouvier C, 1998. Microbial disinfection capacity of municipal solid waste (MSW) composting. J Appl Microbiol 85, 238-46.

Eftoda G, McCartney D, 2004. Determining the critical bulking agent requirement for municipal biosolids composting. Comp Sci Util 12, 208-18. 
European Commission, 2003. Working document on sludge 3rd draft. URL: http://europa.eu.int/comm/environment/waste/sludge/sludge_en.pdf.

Finstein MS, 1989. Activities on composting as a waste treatment technology at the Department of Environmental Science, Rutgers-University. Waste Manage Res 7, 291-94.

Gantzer C, Gaspard P, Galvez L, Huyard A, Dumouthier N, Schwartzbrod J, 2002. Monitoring of bacterial and parasitological contamination during various treatment of sludge. Wat Res 35, 3763-70.

Gea MT, Artola A, Sánchez, A, 2003. Application of experimental design technique to the optimization of bench scale composting conditions of municipal raw sludge. Compost Sci Util 11, 321-29.

Gea T, Barrena R, Artola A, Sánchez, A, 2004. Monitoring the Biological Activity of the Composting Process: Oxygen Uptake Rate (OUR), Respirometric Index (RI), and Respiratory Quotient (RQ). Biotechnol Bioeng 88, 520-7.

Hassen A, Belguith K, Jedidi N, Cherif A, Cherif M, Boudabous A, 2001. Microbial characterization during composting of municipal solid waste. Bioresource Technol 80, 217-25.

Haug RT, 1993. The Practical Handbook of Compost Engineering. Lewis Publishers, Boca Raton, Fl.

Ianotti DA, Pang T, Toth BL, Elwell DL, Keener HM, Hoitink HAJ, 1993. A quantitative respirometric method for monitoring compost stability. Compost Sci Util 1, 52-65. 
Jepsen SE, Krause M, Grüttner H, 1997. Reduction of fecal Streptococcus and Salmonella by selected treatment methods for sludge and organic waste. Wat Sci Technol 36, 203-10.

Jokela J, Rintala J, Oikari A, Reinikainen O, Mutua K, Nyrönen T, 1997. Aerobic composting and anaerobic digestion of pulp and paper mill sludges. Water Sci Tech 36, 181-8.

Larsen KL, McCartney DM, 2000. Effect of C:N ratio on microbial activity and Nretention: bench-scale study using pulp and paper biosolids. Compost Sci Util 8, 14759.

Lasaridi KE, Stentiford EI, Evans T, 2000. Windrow composting of wastewater biosolids: process performance and product stability assessment. Water Sci Tech 42, 217-26.

Lay JJ, Lee YJ, Noike T, 1999. Feasibility of biological hydrogen production from organic fraction of municipal solid waste. Water Res 33, 2579-86.

Liao PH, Jones L, Lau AK, Walkemeyer S, Egan B, Holbek N, 1997. Composting of fish wastes in a full-scale invessel system. Bioresource Technol 59, 163-8.

Maboeta MS, Van Rensburg L, 2003. Bioconversion of Sewage Sludge and Industrially Produced Woodchips. Wat Air Soil Pol 150, 219-33.

Mason IG, Mollah MS, Zhong MF, Manderson GJ, 2004. Composting high moisture content bovine manure using passive aeration. Compost Sci Util 12, 249-67.

McCartney D, Chen H, 2001. Using a Biocell to measure effect of compressive settlement on Free Air Space and microbial activity in windrow composting. Compost Sci Util 9 , 285-302. 
Milne BJ, Baheri HR, Hill GA, 1998. Composting of a heavy oil refinery sludge. Environ Prog 17, 24-7.

Miner FD, Koeing RT, Miller BE, 2001. The influence of bulking material type and volume on in-house composting in high-rise, caged layer facilities. Compost Sci Util 9, 50-9.

Morisaki N, Phae CH, Nakasaki K, Shoda M, Kubota HJ, 1989. Nitrogen transformation during thermophilic composting. J Ferment Bioeng 67, 57-61.

Paluszak Z, Bauza-Kaszewska J, Ligocka A, Olszewska H, Philipp W, 2003. Microbiological studies of composted sewage sludge for agricultural usage. Tierarztliche Umschau 58, 297-303.

Paredes C, Bernal MP, Roig A, Cegarra J, Sanchez-Monedero MA, 1996. Influence of the Bulking Agent on the Degradation of Olive-Mill Wastewater Sludge During Composting. Int Biodet Biodeg 38, 205-10.

Ros M, García C, Hernández T, 2006. A full-scale study of treatment of pig slurry by composting: Kinetic changes in chemical and microbial properties. Waste Manage, available on-line: doi:10.1016/j.wasman.2005.08.008.

Sánchez A, Valero F, Lafuente J, Solà C, 2000. Highly enantioselective esterification of racemic ibuprofen in a packed bed reactor using immobilised Rhizomucor miehei lipase. Enzyme Microb Technol 27, 157-66.

Sesay AA, Lasaridi K, Stentiford E, Budd T, 1997. Controlled composting of paper pulp sludge using the aerated static pile method. Compost Sci Util 5, 82-96.

Sidhu J, Gibbs RA, Ho GE, Unkovich I, 2001. The role of indigenous microorganisms in suppression of Salmonella regrowth in composted biosolids. Wat Res 35, 913-20. 
Trochim, B, 2006. Factorial Design Analysis. Research Methods Knowledge Base. URL: http://www.socialresearchmethods.net/kb/statfact.htm.

U.S. Department of Agriculture and U.S. Composting Council, 2001. Test methods for the examination of composting and compost. Edaphos International, Houston, TX.

U.S. Environmental Protection Agency, 1995. A Guide to the Biosolids Risk Assessments for the EPA Part 503 Rule. URL: http://www.epa.gov/OWOWM.html/mtb/biosolids/503rule/index.htm.

Watanabe H, Kitamura T, Ochi S, Ozaki M, 1997. Inactivation of pathogenic bacteria under mesophilic and thermophilic conditions. Wat Sci Technol 36, 25-32.

Wong JWC, Fang M, 2000. Effects of lime addition on sewage sludge composting process. Water Res 34, 3691-8.

Wong JWC, Li SWY, Wong MH, 1995. Coal fly ash as a composting material for sewage sludge: Effects on microbial activities. Environ Technol 16, 527-37.

Wong JWC, Fang M, Li GX, Wong MH, 1997. Feasibility of using coal ash residues as cocomposting materials for sewage sludge. Environ Technol 18, 563-8. 


\section{Tables}

Table 1: Properties of sewage sludge (ADS and RS) and wood chips used in the experiments

\begin{tabular}{lccc}
\hline \multicolumn{1}{c}{ Parameter } & Anaerobically & Raw Sludge & Wood \\
& Digested Sludge (ADS) & $($ RS $)$ & Chips \\
\hline Water Content (\%) & 67.7 & 72.7 & 5.0 \\
\hline Total Organic Matter (\% dry basis) & 52.8 & 60.4 & 99.4 \\
\hline N-Kjeldhal (\% dry basis) & 2.6 & 2.5 & 0.1 \\
\hline C/N ratio & 8 & 12 & 500 \\
\hline pH & 7.6 & 7.1 & n.d. \\
\hline Conductivity $(\mu \mathrm{S} / \mathrm{cm})$ & 2100 & 1800 & n.d. \\
\hline n.d.:not determined & & & \\
\hline
\end{tabular}


Table 2: Values of the thermophilic time, temperature-time product and objective function for the experimental design for RS and ADS. Normalized values of $X_{1}$ and $X_{2}$ are shown in parentheses.

\begin{tabular}{|c|c|c|c|c|c|c|c|}
\hline \multirow{2}{*}{$\begin{array}{c}\text { Bulking Agent } \\
\text { Particle Size }\left(\mathrm{X}_{1}\right) \\
(\mathrm{mm})\end{array}$} & \multirow{2}{*}{$\begin{array}{l}\text { Bulking:sludge } \\
\text { volumetric } \\
\text { ratio }\left(\mathrm{X}_{2}\right)\end{array}$} & \multicolumn{3}{|c|}{$\mathrm{RS}$} & \multicolumn{3}{|c|}{ ADS } \\
\hline & & $\begin{array}{l}\log _{10} \\
\left(n_{0} / n_{t}\right)\end{array}$ & $\begin{array}{c}\text { Time for } \\
\text { Temp }>45^{\circ} \mathrm{C} \\
\text { (days) }\end{array}$ & $\begin{array}{l}\text { Temp-time } \\
\left({ }^{\circ} \mathrm{C} \cdot \text { day }\right)\end{array}$ & $\begin{array}{l}\log _{10} \\
\left(n_{0} / n_{t}\right)\end{array}$ & $\begin{array}{c}\text { Time for } \\
\text { Temp }>45^{\circ} \\
\text { C (days) } \\
\end{array}$ & $\begin{array}{l}\text { Temp-time } \\
\left({ }^{\circ} \mathrm{C} \cdot \text { day }\right)\end{array}$ \\
\hline $0-5(-1)$ & $1: 1(-1)$ & 2339 & 3.4 & 186 & 522 & 2.5 & 141 \\
\hline $0-5(-1)$ & $2: 1(-0.333)$ & n.d. & n.d. & n.d. & 16 & 2.1 & 109 \\
\hline $0-5(-1)$ & $4: 1(+1)$ & 14 & 1.0 & 53 & 4 & 0 & 0 \\
\hline $5-10(-0.333)$ & $1: 1(-1)$ & 522 & 3.5 & 196 & 303 & 2.8 & 151 \\
\hline $5-10(-0.333)$ & $2: 1(-0.333)$ & 0 & 0 & 0 & 1 & 1.7 & 84 \\
\hline $5-10(-0.333)$ & $4: 1(+1)$ & 0 & 0 & 0 & 0 & 0 & 0 \\
\hline $10-20(+1)$ & $1: 1(-1)$ & 0 & 0 & 0 & 0 & 0 & 0 \\
\hline $10-20(+1)$ & $2: 1(-0.333)$ & 0 & 0 & 0 & 0 & 0 & 0 \\
\hline $10-20(+1)$ & $4: 1(+1)$ & 0 & 0 & 0 & 0 & 0 & 0 \\
\hline
\end{tabular}

n.d.:not determined 
Table 3: Parameters of the equation fitting the results of experimental design for RS and ADS

\begin{tabular}{ccc}
\hline Parameter & Raw Sludge & \multicolumn{2}{c}{ Anaerobically Digested Sludge } \\
\hline $\mathrm{X}_{10}$ & -0.909 & -0.779 \\
\hline $\mathrm{X}_{20}$ & -1.038 & -1.082 \\
\hline $\mathrm{a}$ & & 652.4 \\
\hline $\mathrm{b}$ & 2487.9 & -0.371 \\
\hline $\mathrm{c}$ & -0.329 & -0.272 \\
\hline $\mathrm{r}$ & -0.173 & 0.99990 \\
\hline
\end{tabular}




\section{Legends to Figures}

Figure 1: Scheme of the $100 \mathrm{~L}$ composting vessel (not to scale).

Figure 2: Examples of determination of the objective function for 4.5-L experiments for a) RS: 0-5 mm and 1:1; b) ADS: 0-5 mm and 2:1. Composting temperature (dashed line), $\mathrm{k}_{\mathrm{D}}$ (solid line). Horizontal dotted line corresponds to $45^{\circ} \mathrm{C}$, limit of thermophilic conditions.

Figure 3: Surface response for the fitted objective function. Objective function $\left(\log _{10}\left(\mathrm{n}_{0} / \mathrm{n}_{\mathrm{t}}\right)\right)$ is plotted for the whole range of normalized values of the factors considered ( $\mathrm{X}_{1}$ : bulking agent particle size; $\mathrm{X}_{2}$ : bulking agent: sludge volumetric ratio) for a) $\mathrm{RS}$; b) ADS.

Figure 4: Evolution of control parameters during composting time for 100-L scale experiments for a) RS; b) ADS. Upper graph: Temperature (solid line) and OUR (triangles); lower graph: $\% \mathrm{O}_{2}$ (solid line), $\% \mathrm{CO}_{2}$ (dotted line) and RQ (circles). 
Fig 1.

Data acquisition and control system

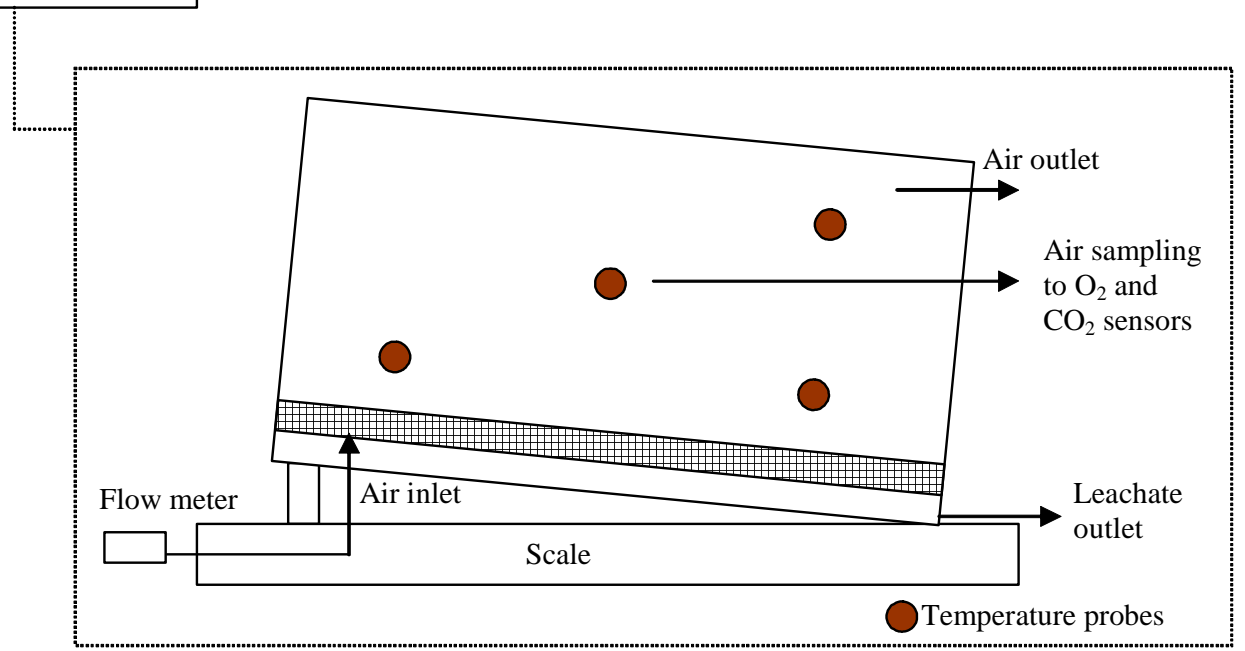


Fig 2.a)

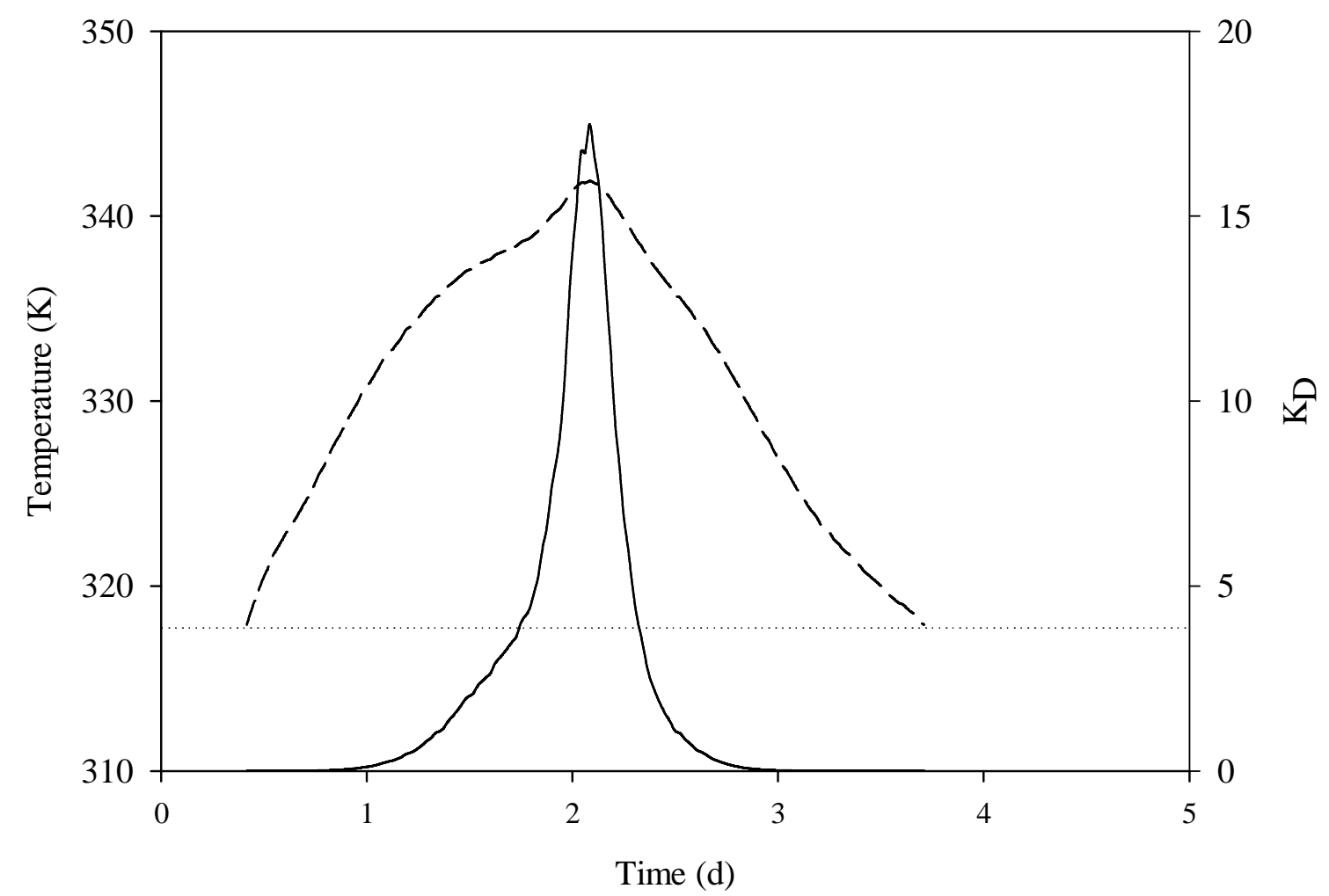


Fig. 2.b)

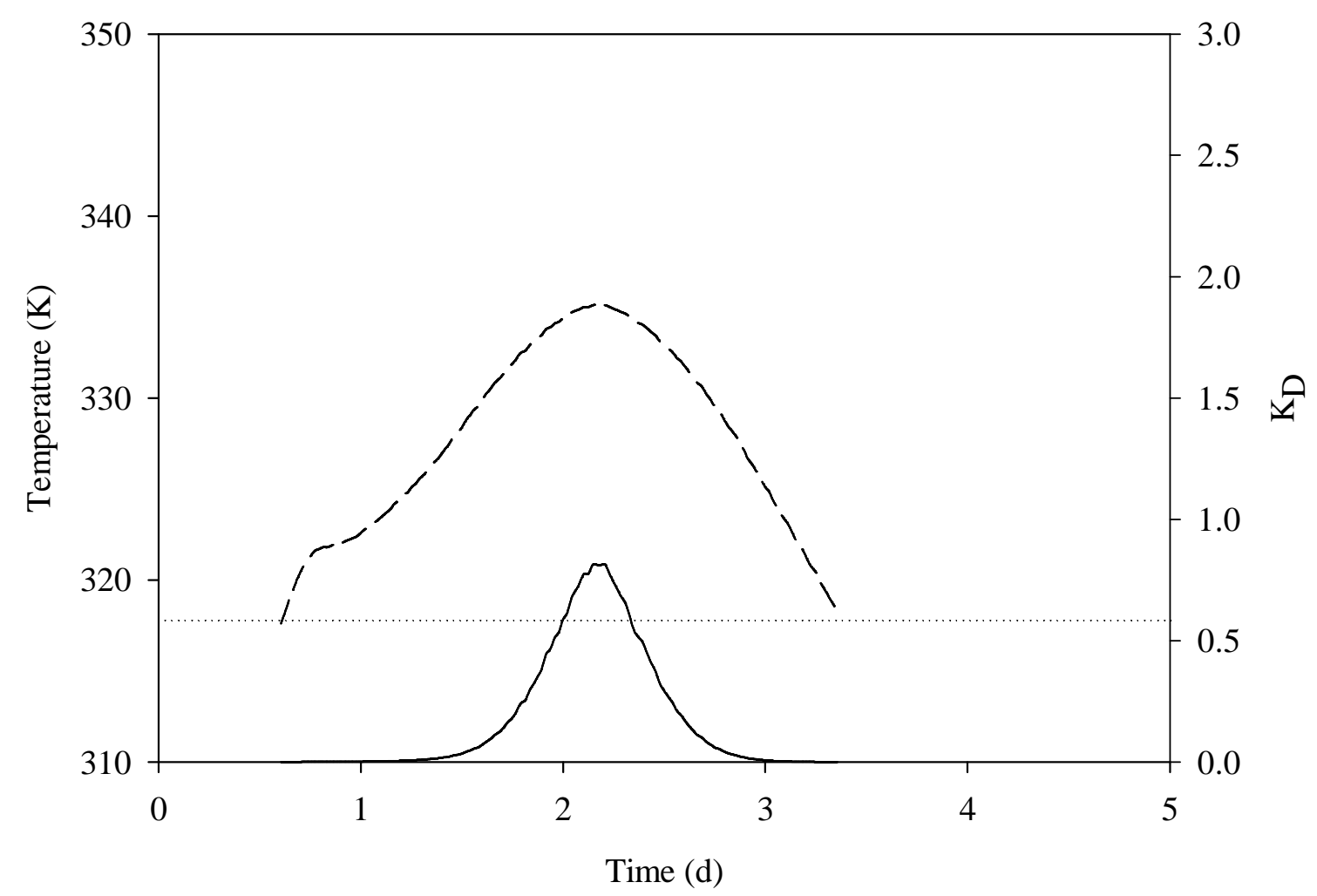


Fig. 3.a)

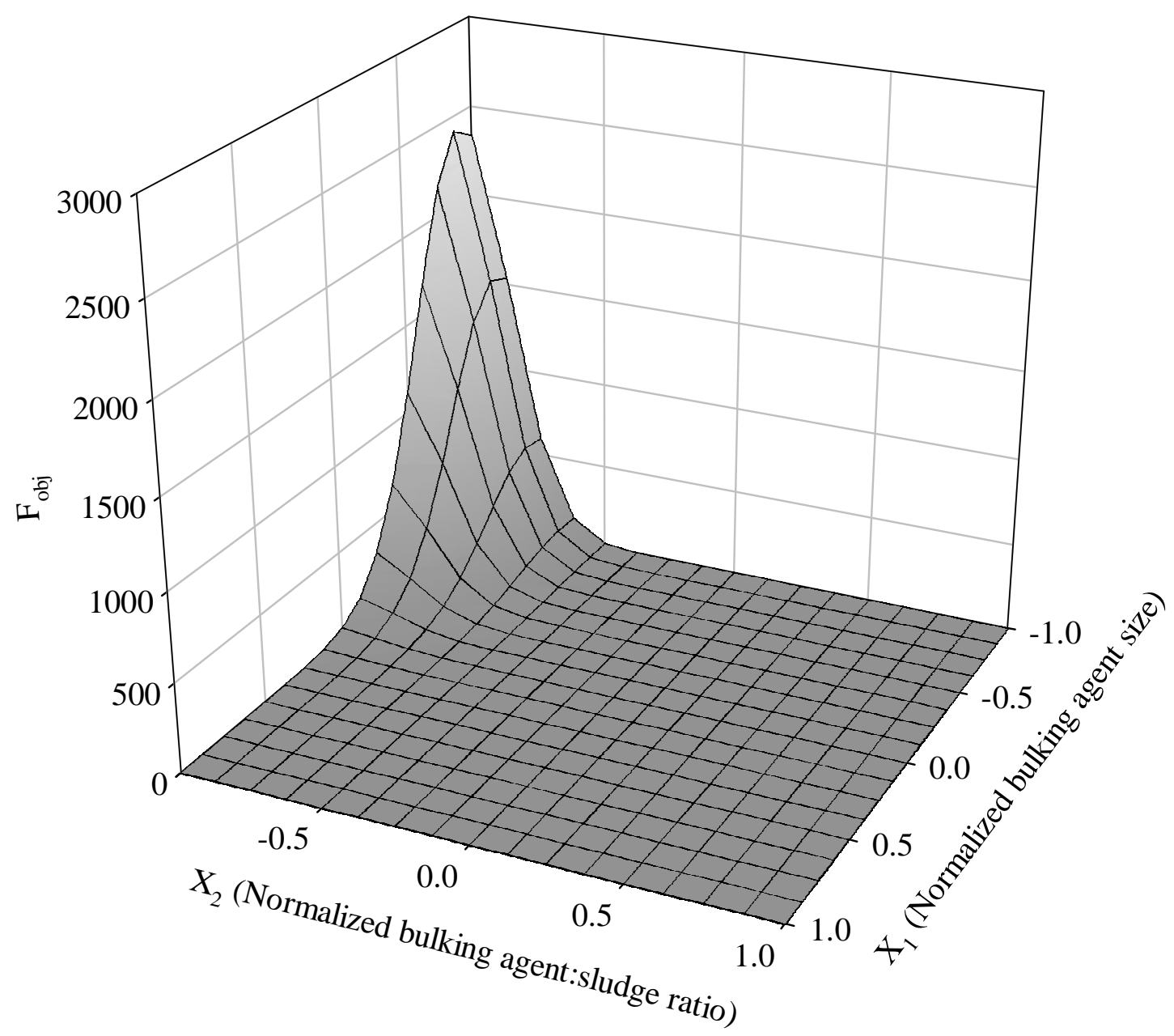


Fig. 3.b)

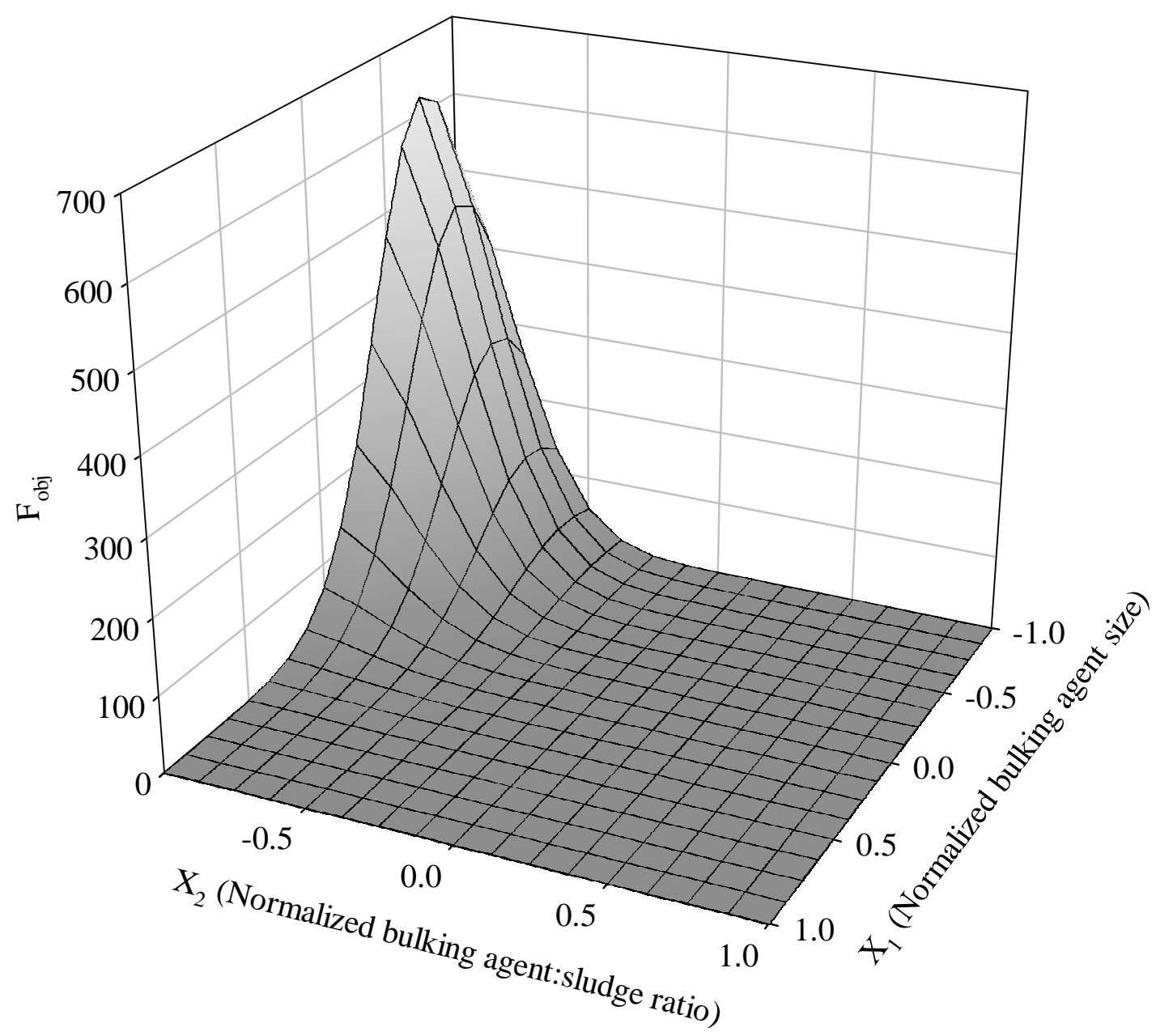


Fig. 4.a)

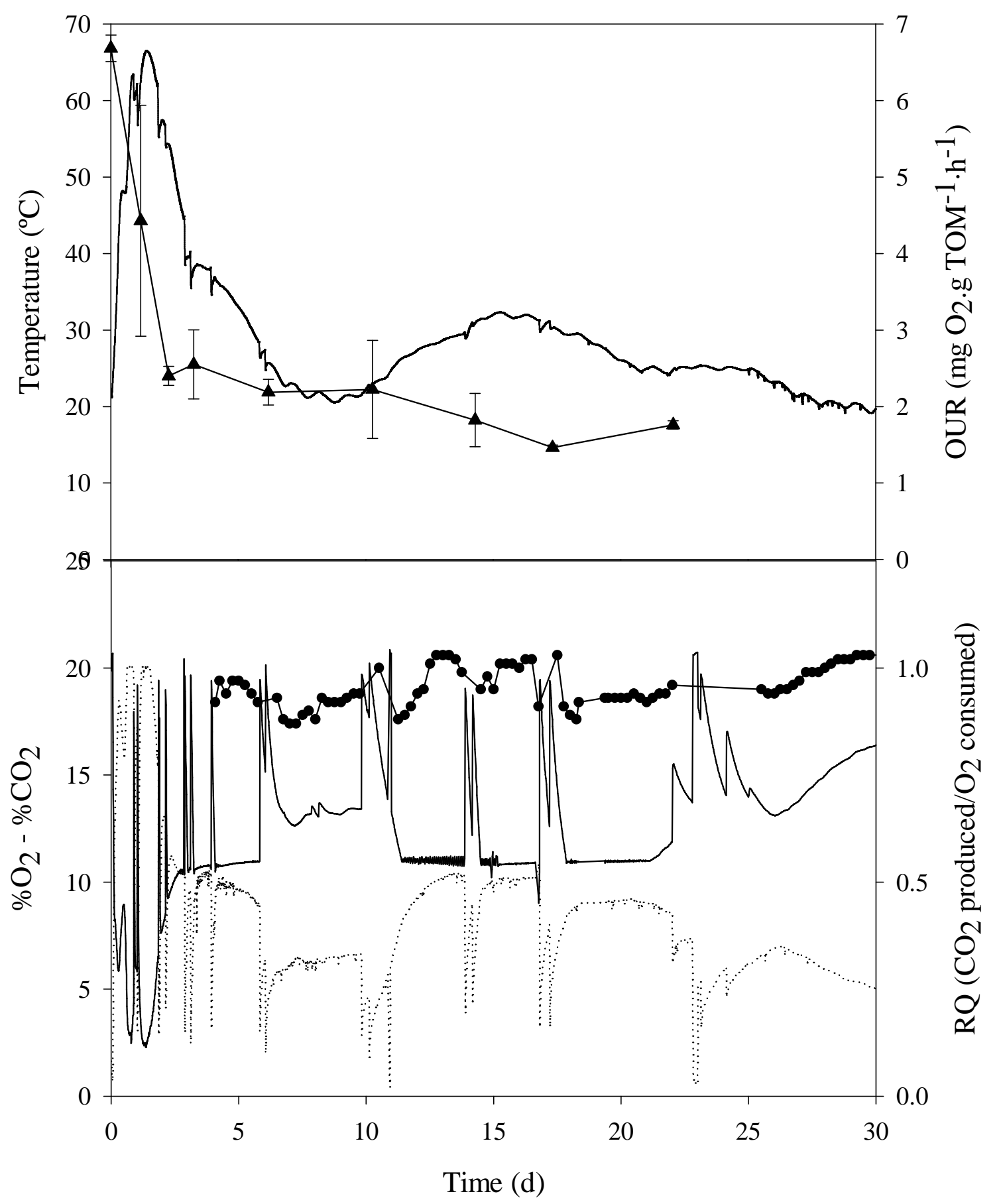


Fig. 4.b)

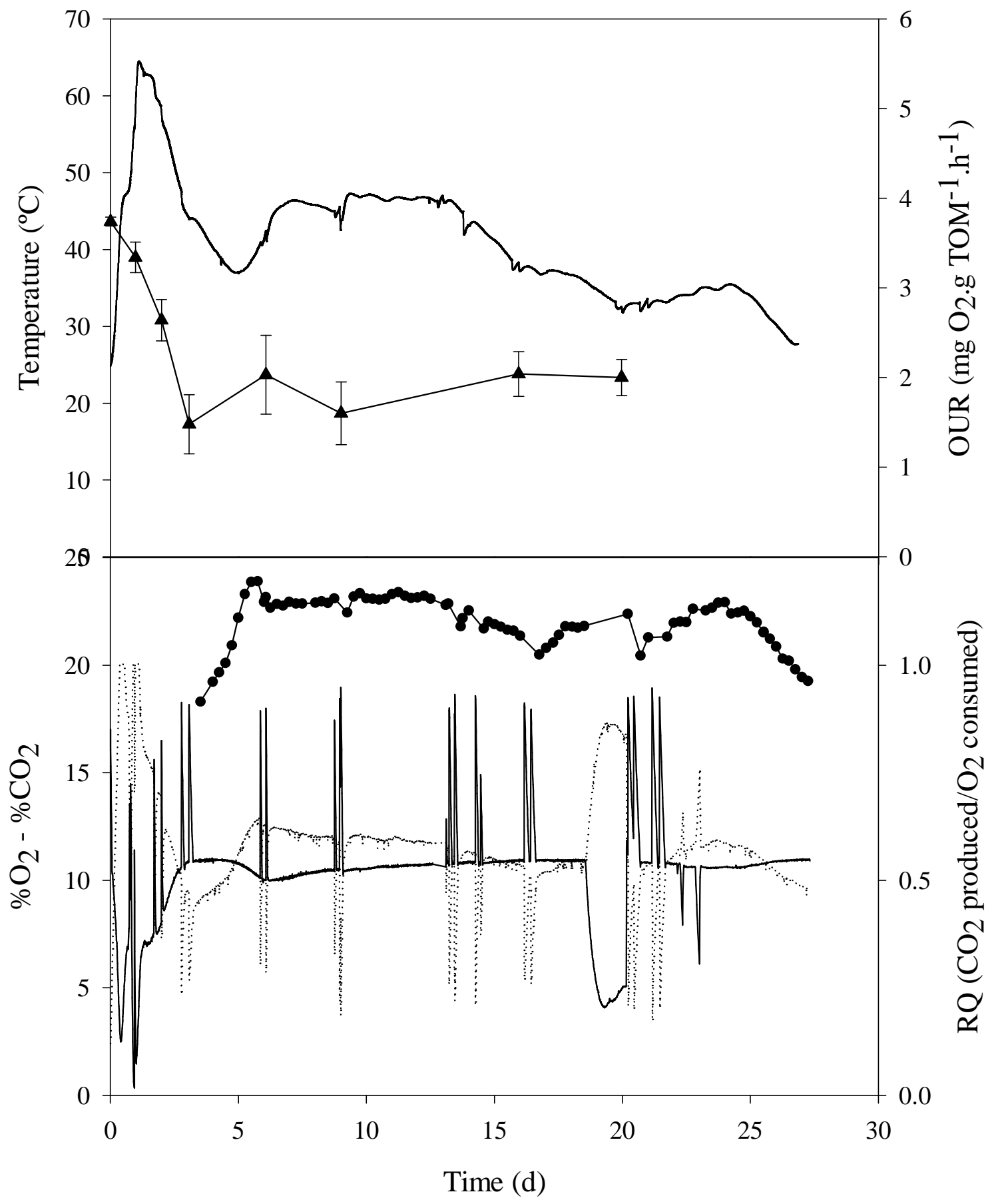

